\title{
Learning under the assessment of the higher-level student, in times of COVID-19
}

\section{El aprendizaje bajo la valoración del estudiante de nivel superior, en tiempos de la COVID-19}

\author{
GONZÁLEZ-HERRERA, Karina Concepción†**
}

Universidad Tecnológica Metropolitana, México

ID $1^{\text {st }}$ Author: Karina Concepción, González-Herrera / ORC ID: 0000-0002-1743-2614 - Researcher ID Thomson: R3825-2018, CVU CONACYT ID: 256147

DOI: $10.35429 /$ JCT.2020.12.4.24.33

Received: January 25, 2020; Accepted June 30, 2020

\begin{abstract}
Learning through virtual scenarios is today the way in which education has to reach higher level students, however it contracts, multiple scenarios, which do not only integrate the teaching or guide of the current subject, it also encompasses the tasks, practices, exercises, among others, that could value learning, however, it is there where the student's perception becomes valuable when considering the aspects that strengthen knowledge, learning and skills, under the modality that the conditions of health allow, considering the presence of the pandemic derived from the SARS-CoV2 virus. The purpose of this document is to analyze the perception of the higher-level student regarding the guidance provided regarding the subjects taken in time of the COVID-19 pandemic as a result of the transition from face-to-face classes to online teaching, considering the learning achieved by the student. Among the results that were obtained, it can be mentioned that face-to-face learning is today the scenario that is longed for among students, however, it is the scenario that today cannot be accessed, being valued the level of learning, skills and knowledge acquired in person with a greater presence by more than $90 \%$ of the study subjects. Contrary to this, the orientation, and solution of doubts under the various virtual scenarios, the doubts generated and the clarification of the doubts present regarding the tasks, practices, among others, are correctly and positively perceived, that is, they were solved with an arithmetic mean between both aspects of $88 \%$.
\end{abstract}

Learning, Online learning, Virtual learning

\begin{abstract}
Resumen
El aprendizaje mediante escenarios virtuales es hoy la forma en cómo tiene la educación para llegar con los estudiantes de nivel superior, sin embargo esta contrae, múltiples escenarios, que no integran únicamente la enseñanza o guía de la asignatura en curso, también engloba, las tareas, prácticas, ejercicios, entre otros, que pudieran valorar el aprendizaje, sin embargo, es allí en donde la percepción del alumno se vuelve valiosa al considerar los aspectos que fortalecen los conocimientos, el aprendizaje y las competencias, bajo la modalidad que las condiciones de salud permiten, considerando la presencia de la pandemia derivada del virus SARS-CoV2. El objeto del presente es analizar la percepción del estudiante de nivel superior con respecto a la orientación brindada relativa a las asignaturas cursadas en tiempo de la pandemia COVID-19 como resultado de la transición de las clases presenciales a la enseñanza en línea, considerando el aprendizaje alcanzado por el alumno. Dentro de los resultados que se obtuvieron se puede mencionar que el aprendizaje presencial es hoy el escenario que se añora entre los estudiantes, sin embargo, es el escenario que al día de hoy no se puede acceder, siendo valorado el nivel de aprendizaje, competencias y conocimientos adquiridos de forma presencial con mayor presencia por más del $90 \%$ de los sujetos de estudio. Contrariamente a ello, la orientación, y solución de dudas bajo los diversos escenarios virtuales se percibe de forma acertada y positiva las dudas generadas y la aclaración de las dudas presentes con respecto a las tareas, prácticas, entre otros, es decir se solucionaron con una media aritmética entre ambos aspectos del $88 \%$.
\end{abstract}

Aprendizaje, Aprendizaje en línea, Aprendizaje virtual

Citation: GONZÁLEZ-HERRERA, Karina Concepción. Learning under the assessment of the higher-level student, in times of COVID-19. Journal Computer Technology. 2020. 4-12:24-33.

\footnotetext{
* Correspondence to the author (Email: karina.gonzalez@utmetropolitana.edu.mx).

$\dagger$ Researcher contributing as first author.
} 


\section{Introduction}

On March 11, 2020, the World Health Organization (WHO), through its director general Tedros Adhanom Ghebreyesus, declared that COVID-19 went from an epidemic to a pandemic worldwide (Arroyo, 2020). In the same way, the director of the WHO emphasized that all sectors will be affected, in that sense he mentions that each sector must do the same to face the pandemic. Among the symptoms that were identified of the coronavirus (COVID 19) of the SARS-CoV2 virus, there is "fever $(>90 \%$ of cases), malaise, pulmonary infiltrates when performing chest X-ray, dry cough (80\%), dyspnea (20\%) and respiratory distress (15\%) considering the first 5 days of incubation on average "(Cohen \& Normile, 2020; Hui, Azhar, Madani, Ntoumi, Kock, Dar, et al, 2020; Bogoch, Watts, Thomas -Bachli, Huber, Kraemer, Khan, 2020) cited in (Cortés, 2020). According to severity and need for management, it is classified as mild-moderate $(80 \%$, nonsevere pneumonia), severe $(15 \%$, severe pneumonia) and critical (5\%, SARS, sepsis and shock) disease. What was identified was that children, adolescents and young people under 24 years of age have mild disease, adults between 25 and 65 years old evolve, although they do not present risk factors, but those over 65 years with comorbidity are the most vulnerable. The identified risk factors are: cardiovascular disease, arterial hypertension (HT), diabetes and chronic lung, liver or kidney disease. (Deng \& Peng, 2020; Ralph et al. 2020; Huang, et al. 2020; Zhu, et al. 2020) cited by (VillegasChiroque, 2020).

The coronavirus (COVID-19) is the first pandemic in human history in which technology and social media are being used on a massive scale to keep people safe, productive and connected despite being physically separated (War, 2020).

However, not all sectors of the economy took the pace of technology and internet connection, because physical spaces and contacts between people meet a distance parameter to avoid contagion, which reduces the possibility to enjoy certain products and services that are offered such as tourist destinations, the purchase of shoes that needs to be to the taste of customers, among other examples.
The reduction in mobility generates a decrease in gasoline consumption and an increase in the use of electrical energy in homes. Similarly, the non-existence of homogeneous territories with internet access, and the resources to have a laptop and various means for connectivity must be considered.

Before the diagnosis of the first positive case of COVID-19 on February 26, 2020 in Brazil (La Jornada, 2020), immediately the scenario was presented in Mexico on February 28, 2020 (Adn40, 2020), in the Yucatan peninsula The first case was present on the following dates: Campeche on March 22 according to (La Jornada, 2020), Quintana Roo reports the first case on March 13 by (Quintana Roo Health Secretariat, 2020), the same day in Yucatán it is announced (Government of the State of Yucatán, 2020).

Faced with this health contingency, the government of Mexico decreed the following in accordance with (Cruz Reyes \& Patiño Fierro, 2020):

Avoid attending workplaces, public spaces and other crowded places, adults over 65 years of age or over and groups of people at risk of developing serious disease and / or dying from it, who at all times and in a way paid leave, they will enjoy their salary and other benefits.

- Temporary suspension of school activities at all levels, until April 17, 2020, as established by the Secretary of Public Education.

Temporary suspension of the activities of the public, social and private sectors that involve the physical concentration, transit or movement of people from the entry into force of this Agreement and until April 19, 2020. 
In relation to the suspension of school activities, the longer the time, the greater the negative impact on students from homes with high vulnerability indicators, as well as the detection of less resilience, since many students have fewer learning opportunities, because they do not have the appropriate means and technological tools for this, among other obstacles that are presented directly to parents in caring for them (Fernández, Hernández, Nolasco, de la Rosa, \& Herrera, 2020). However, the results become uncertain, which can be measured as the virtual teaching period progresses and the semesters, semesters and educational cycles conclude.

On April 20, 2020, records of 8,772 positive cases of people with COVID-19 were presented in Mexico, with 712 deaths (Secretariat of Health Mexico, 2020). In the Yucatan peninsula on the same date there were positive records of 614 people infected with COVID-19, which represented $7 \%$ with respect to the national data, with a total of 47 deaths in the territory, the above positioned the state of Quintana Roo (30 deaths), as an entity with the highest cases, Campeche was the state with the least presence of the pandemic in its inhabitants (63 positive cases and 3 deaths) (El Universal, 2020), in view of this situation the peninsula does not present a direct association of the behavior of infections with the number of inhabitants of the entities of Quintana Roo and Yucatán, considering that the total population of the peninsula is equivalent to $4,498,671$ inhabitants (National Institute of Statistics and Geography [INEGI], 2015), where Campeche It has $20 \%$ of the population in its territory, $46.6 \%$ is in Yucatán and 33.4\% lives in Quintana Roo. It should be noted that the state of Quintana Roo is one of the ones with the highest incidence of positive infections to COVID-19. However, the measures were intensified, due to the fact that the pandemic in Mexico reached phase 3, on March 21, 2020, which consisted of strengthening these as the distancing between people, reducing mobility in public spaces, as well as promote awareness in citizenship. Since non-essential economic activities no longer physically maintain the offer of their services and / or products.
Face-to-face teaching in educational institutions is maintained in virtual learning scenarios, before an uncertain date of return to normality or when infections are minor and the traffic light of the corresponding entity is green and the health conditions of the inhabitants allow it (that is, the return to face-to-face classes is safely for students of all academic levels), in this study the higher level of studies is approached, where the transition to the virtual modality has been generated under complex and uncertain scenarios for these, considering the socioeconomic conditions that currently present the same.

\section{Problem Statement}

At the beginning of the pandemic and in view of the suspension of academic and school activities, the use of platforms such as Microsoft office 365, Zoom, Google meet, Classroom, etc. was promoted to continue with educational programs in institutions, however, many educational institutions do not have or did not have the necessary digital technology infrastructure to teach online classes, nor were the subjects designed to be taught in virtual mode. It was identified that the same economic possibility of access to the Internet and computers is presented in the homes of people who have the least (marginalized). In the absence of prior planning, virtual (online) teaching and learning are not guaranteed (Economic Commission for Latin America and the Caribbean [ECLAC], 2020). However, the time to conclude the current semester (January-April 2020) under the educational modality studied, was with an advance of approximately $70 \%$.

Faced with this pandemic, all public and private educational levels resort to distance education as necessary. Regardless of the amount of resources, teacher training or preparation, the measure is implemented to protect students, teachers and the academic community in general, following government guidelines. (Valdez-García, and others, 2020). 
This has generated educational progress, however, it does not allow the evaluation of competencies in accordance with the planning of teaching by subject that is taught. In this sense, it is possible to identify the disparity related to access to technological tools and equipment to take the subjects with respect to students, in such a way that, identified the above for (Sánchez Mendiola, et al., 2020) indicate as a result of a study directed towards teachers that becomes relevant to direct "supports for students who do not have access to technological resources so that they can join this form of work", that is, to guide academic training through complementary means to conclude on time the semester or semester completed. It should be noted that this requires the attitude, disposition, enthusiasm and interest of the student, since, without this, any effort from the counterpart (teachers and institutions) it will hardly have the expected effect.

\section{Objective}

Analyze the perception of the higher-level student regarding the guidance provided regarding the subjects taken in time of the COVID-19 pandemic as a result of the transition from face-to-face classes to virtual teaching, considering the learning achieved by the student.

\section{Research question}

What is the assessment assigned to virtual learning considering the orientation, guidance and clarification of doubts regarding tasks, practices and projects from the student's perception in the period March-August 2020?

\section{Study justification}

This project will allow to propose the educational strategies for the pertinent virtual teaching required, to attend in a timely manner and in accordance with the needs identified in the planning of the teaching of the teachers, with a local approach, aimed at education students. higher, to reduce academic loss and promote educational continuity. It will be possible to identify the areas of opportunity in the virtual learning of higher education students, to specify the teaching processes for adaptability.
Being that learning through virtual means refers to the knowledge obtained through technological means that guide and orient the progress of the assigned student and that he could replicate the information in other settings (home, office, social environment, etc.). Being that meaningful learning is conceived as "the interaction between previous knowledge and new knowledge and that this interaction is not literal and not arbitrary. In this process, new knowledge acquires meaning for the subject and previous knowledge acquires new meanings or greater cognitive stability" (Moreira, 2012).

\begin{tabular}{|c|c|}
\hline Advantage & Author \\
\hline 1. Excellent lessons on the net & \multirow{2}{*}{ (Feito, 2020) } \\
\hline $\begin{array}{l}\text { 2. Instructors who know how to } \\
\text { communicate, using different techniques } \\
\text { in teaching }\end{array}$ & \\
\hline $\begin{array}{l}\text { 3. Students have the opportunity to expand } \\
\text { their cognitive experience by using new } \\
\text { technologies as tools for constructivist } \\
\text { learning (p. 164) }\end{array}$ & $\begin{array}{l}\text { Hernández } \\
\text { (2008) citado } \\
\text { en (Vargas \& } \\
\text { Jiménez, 2013) }\end{array}$ \\
\hline $\begin{array}{l}\text { 4. The recipients can be variable, from the } \\
\text { initial ones, from researchers to students of } \\
\text { different educational levels, as well as the } \\
\text { geographic scope of reaching is unlimited, } \\
\text { specifically using learning and knowledge } \\
\text { technologies (TAC) }\end{array}$ & $\begin{array}{l}\text { (Verdencia, } \\
\text { Cecilia, \& } \\
\text { Jimena, 2016) }\end{array}$ \\
\hline $\begin{array}{l}\text { 5. It allows "integration with other } \\
\text { electronic tools, it can become a central } \\
\text { means of dissemination, communication } \\
\text { and collaborative work", considering the } \\
\text { creativity and commitment of the teachers } \\
\text { who teach under this modality (p. } 3 \text { ). }\end{array}$ & $\begin{array}{l}\text { (Galeana- } \\
\text { Victoria, } \\
\text { Flores-Azcano, } \\
\text { Gacía-León, \& } \\
\text { Ruiz-Nartínez, } \\
\text { 2016) }\end{array}$ \\
\hline $\begin{array}{l}\text { 6. It is to provide an educational space in } \\
\text { which teachers and students can develop } \\
\text { their academic activities, finding in these } \\
\text { environments their own community, } \\
\text { intercommunicating effectively with the } \\
\text { use of tools that support and facilitate the } \\
\text { teaching-learning processes through } \\
\text { network (Salinas, 2011). }\end{array}$ & (Salinas, 2011) \\
\hline $\begin{array}{l}\text { 7. Depending on the degree of skills and } \\
\text { knowledge that teachers have of the } \\
\text { subjects (it will be the result of teaching- } \\
\text { learning) and the motivation that is } \\
\text { transmitted through virtual platforms, } \\
\text { linked to the use of ICT. }\end{array}$ & $\begin{array}{l}\text { (Díaz, Peña, } \\
\text { Macías, } \\
\text { Moreno, }\end{array}$ \\
\hline Disadvantages & Author \\
\hline $\begin{array}{l}\text { 1. Online instructors are not always } \\
\text { teachers. }\end{array}$ & (Feito, 2020) \\
\hline $\begin{array}{l}\text { 2. Dropout, lack of motivation and a } \\
\text { feeling of loneliness in students or } \\
\text { institutional problems, as one of the facts } \\
\text { to give the same recognition that studies } \\
\text { deserve (p. 164). }\end{array}$ & \\
\hline $\begin{array}{l}\text { 3. In this sense, the main disadvantage is } \\
\text { the distractions to which both students and } \\
\text { the instructor, professor or teacher who use } \\
\text { virtual educational platforms are exposed, } \\
\text { when having access to the Internet. }\end{array}$ & $\begin{array}{l}\text { In (Marqués, } \\
\text { 2000) cited by } \\
\text { (Vargas } \quad \text { \& } \\
\text { Jiménez, 2013) }\end{array}$ \\
\hline $\begin{array}{l}\text { 4. Some of the limitations in the use of e- } \\
\text { elearnig (use of ICTs to transmit } \\
\text { information and knowledge) in Ecuadorian } \\
\text { higher education, were caused by } \\
\text { ignorance of the functions and } \\
\text { characteristics of the virtual tutor, lack of } \\
\text { preparation and laziness of teachers. }\end{array}$ & \\
\hline
\end{tabular}

GONZÁLEZ-HERRERA, Karina Concepción. Learning under the assessment of the higher-level student, in times of COVID-19. Journal Computer Technology. 2020 


\begin{tabular}{|l|l|}
\hline $\begin{array}{l}\text { 5. The limitations in the development and } \\
\text { practice of oral skills, and the lack of } \\
\text { interaction or direct contact with } \\
\text { classmates and the teacher (p.12). }\end{array}$ & \\
\hline $\begin{array}{l}\text { 6. Based on the results of the study carried } \\
\text { out by the authors, they determine that, the } \\
\text { greater volume of higher-level students }\end{array}$ & \\
consider virtual classes little \\
understandable, considering the presence \\
of various distractors that they present in \\
the virtual space or the poor quality of the \\
internet.
\end{tabular}

Table 1 Advantages of teaching through virtual learning media

Source: Self made

\section{Methodology}

Among the characteristics that distinguish the quantitative research approach, it is identified that, to obtain the information, it uses the collection and later analysis of the data collected to answer the research questions posed and test the hypotheses generated from the study, also the numerical data allow to establish the behavior patterns of the study subjects, among others mentioned (Vega-Malagón, and others, 2014). The research approach used was quantitative, considering $94 \%$ confidence, with a value for $\mathrm{Z}$ equivalent to 1.88 and for the proportions for $p$ and $\mathrm{q}(0.5)$ respectively, the estimation error is equal to 0.05 , with a total of questionnaires to apply. of 418, collected in total are 442 instruments. Which were applied to higher-level students studying in Yucatán, with a record of 120,290 students in the state (Ministry of Public Education [SEP], 2019). Derived from the above, we proceeded to select the data that were part of the present result that represent the students of the technological universities in Yucatan, being of the 5 institutions mentioned in the entity, in two of them the students who answered the instrument, equivalent to $94 \%$ confidence, with a margin of error of 0.06 , with $\mathrm{p}$ and $\mathrm{q} 0.5$ respectively, with a calculated sample of 245 questionnaires and with a total record of 258 applied instruments, equivalent to $58 \%$ and the remaining percentage students from other educational institutions were addressed.
The instrument designed was a questionnaire which was standardized and, according to its definition, it is used to collect information on the work of a sample of people (Meneses, 2016, p. 9). Made up of a total of 51 items, with a multiple response option.

\section{Results}

Based on the information collected, it was obtained that the profile of the study subjects is mainly female with 58\%. Regarding the data collected on sex, it is identified that it has a negative asymmetry -0.316 , which indicates that the values are gathered to the right of the mean. With a platicúrtic name kurtosis derived from its negative distribution -1.915. Families obtain between 1 to 2 minimum income wages (from $\$$ 3,747 to $\$ 7,492$ ), the average income being $\$$ 5,881 pesos in the families of the students studied. With positive asymmetry equivalent to 0.970 and a kurtosis called leptokurtic with a value of 1.449 . In relation to the number of members per dwelling, it is obtained that the arithmetic mean is equal to 4.76 equal to 5 people. With a high positive asymmetry value of 1,068 and a leptokurtic kurtosis of 2,476 (see table 1). As a result of the above, it was possible to determine that with respect to monthly income and the number of inhabitants per dwelling there is a low correlation of 0.28 .

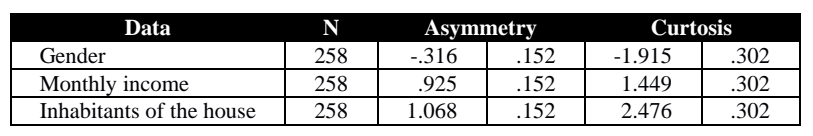

Table 2 General characteristics of the study subjects Source: Self made

On the other hand, it is possible to determine that the consultation sites that are frequented for reasons of illness are public health institutions (SSA, IMSS, ISSSTE, etc.) with $57 \%$, followed by medical attention in various pharmacies with $24.4 \%$ and with $12.4 \%$ private medical offices. An arithmetic mean of 4.38 and a standard deviation of 1.046 are identified. The perception of health services that is equivalent to an assessment of fair, which is related to $52.3 \%$ of frequency, followed by $23.3 \%$ as good and with $13.6 \%$ as bad. Returns a mean of 2.96 with a standard deviation of 0.896 . The existing correlation between the place to which one goes and the perception of public services is known as a negligible correlation with 0.096 . 
Regarding the main sites consulted by higher-level students, to be informed of the behavior of COVID-19, it is firstly social networks with $37.5 \%$, followed by information generated through television by $26.9 \%$, and in the third place are the official health pages of the WHO, SSA, IMSS, ISSSTE, etc., (see figure 1). The first consultation scenario being the most fragile, since false information or news can circulate online that can encourage alarm and generate negative situations in the population. In addition to this, the educational programs were not designed to be taught online, so many of the teachers do not have infrastructure in their homes, such as internet and / or computer to monitor their classes and in the complementary phase the student does not always It has the equipment required for learning its subjects for the period covered by the higher education system. But the final assessment of learning will be reached at the end of the educational period, where the economic situation of the country has slowed down, and the homes of student students will be affected in income. Based on the sample size determined for the present study, a similar behavior is identified (see table 3 ).

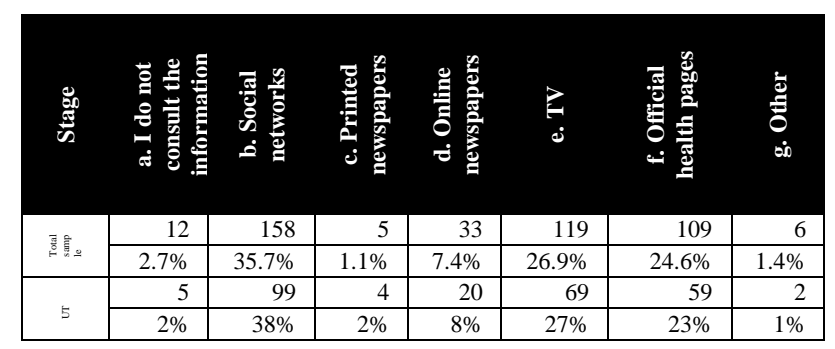

Table 3 COVID-19 behavior consultation spaces Source: Self made

In the months (from March to August 2020) with the presence of COVID-19, virtual assistance and monitoring by the student as well as the teacher was important for teaching and online classes, in that sense regarding the doubts that arose, the clarification of them and the means used to do so were paramount. It was obtained that, regarding the clarity of the orientation of the doubts towards the tasks, practices, exercises and others generated by the teachers, $85 \%$ of the interviewed students indicated that it was clear, $91 \%$ of the study subjects indicated that the doubts raised were clarified in their entirety and in relation to the hours in which the consultations and follow-ups were generated, $44 \%$ indicated that it was not during the class schedule (see figure 1).
Given this last answer, it is important to mention that the definition of the schedules assigned to doubts by the teachers, provided better results for the students in relation to the doubts generated by the synchronous virtual class sessions.

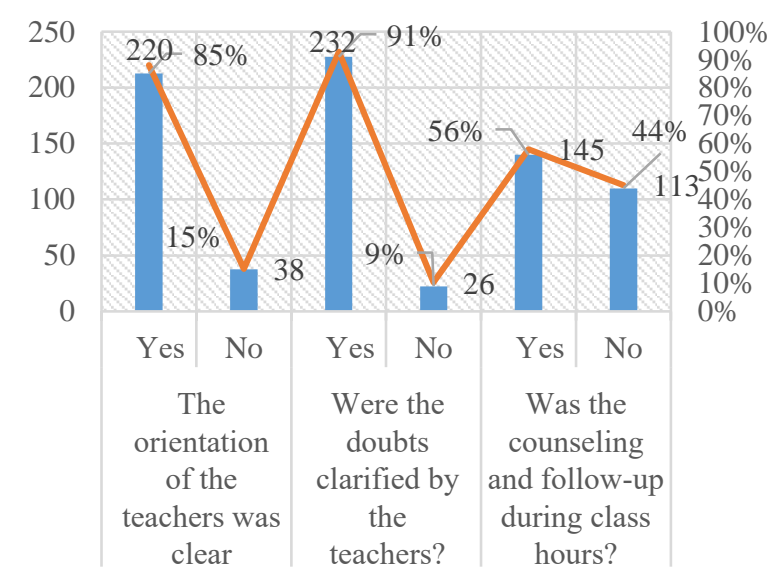

Figure 1 Perception of the higher-level student in relation to the doubts of the activities, tasks, exercises Source: Self-made

Derived from the above, it was calculated that the existing correlation between the clarified doubts and the clarity of the doubts with a measure of 0.515 identified as a moderate correlation; a 0.228 with a low correlation of the advice and follow-up with respect to the clarity of the guidance generated and a negligible correlation with 0.120 between the hours of the counseling and follow-up with respect to the clarification of the doubts generated from the online sessions.

In the same way, it was determined that under the perception of the higher level student, face-to-face teaching is the modality in which it obtains better results regarding knowledge, clarity of doubts and competencies to be achieved with more than $90 \%$ of the mentions ( see figure 3 ). That is, the notion of learning in strengthening it, is acquired from the student's perspective through face-to-face teaching, which is what is missed, during the time of the pandemic, but it is the one that it cannot be accessed due to current conditions. 


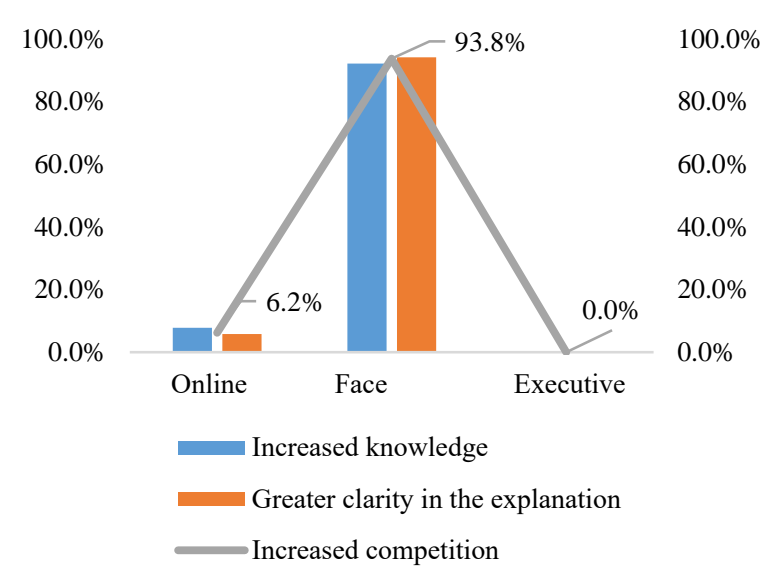

Figure 2 Assessment of teaching based on the modality Source: Self-made

\section{Discussion of results}

It can be mentioned that online teaching under the synchronous and asynchronous sessions used for the generation of classes has generated in the students an absence of concentration in the first place, in turn provoked as indicated by Castaño, R., Jenaro, C., \& Flores, N. (2017) citing Pascual (2003) for the absence of human contact and the feeling of belonging to the institution to which he belongs, as well as a lack of motivation for an educational continuity, among other circumstances of the modality. To this must be added the health conditions that prevail in the world and the infrequency of physically interacting with other individuals (Covid-19), as well as the growth of the feeling of stress and claustrophobia, among other circumstances that affect the concentration of upper-level students.

\section{Conclusions}

In teaching, the perception of students becomes relevant because with their contributions, a proposal for improvement or solution can be proposed to the areas of opportunity that they detect, today we face the challenges of the new normal where, the Education is in a process of adjustment and adaptation of its thematic contents, low and with the technological resources that the institutions have, these being limited and scarce, especially when they are public institutions, in which the present study was focused, before it the next:

1. Generate virtual scenarios $100 \%$ online (except for the asynchronous form, promoting independent and autonomous study) in permissive subjects
2. Establish virtual scenarios with synchronous orientation, under the established times of concentration of the students and based on the thematic content of the class (allusion to the freedom of teaching in virtual scenario), that is, classes of no more than 90 minutes.

3. Establish the regulation of the subject from the beginning of classes (by the teacher), making clear the way of teaching, the tone of the teacher's voice and the forms of communication and communication channels between the teacher and the students.

4. Establish agreements regarding interruptions to orientation (synchronous classes) when it is appropriate and when it is not.

5. Clarify the importance of the teacher taking control of the microphones, to avoid disorders or interruptions that are not their own, in class sessions.

6. Assignment of the times of the doubts clarification sessions, when the evaluation instruments are presented and explained.

7. Establish the responsibility and commitment that students contract in the face of virtual absence and lack of concentration to the explanations of the assessment instruments of the subject by partial.

8. Establish co-responsibilities for monitoring the sessions and recording them for subsequent repetition by the students, in extemporaneous time.

9. Provide complementary materials to students, as well as search spaces for them.

10. Promote the use of academic databases, to strengthen the results of research to the awareness of students

11. Establish clearly that the responsibility for synchronous virtual assistance corresponds exclusively to the student. 
12. Define the respect required with the fulfillment of the times and schedules of delivery of the evaluation instruments, tasks, practices, exams and others as a result of the subjects.

13. Refine the requirements of the background content and the structure of the tasks, activities, projects and others that derive from the subject.

\section{References}

Adn40. (28 de Febrero de 2020). Confirman el primer caso de coronavirus COVID-19 en México. Covid. Retrieved May 30, 2020, obtained from: https://www.youtube.com/watch?v=7S4YoKOj $\mathrm{n} 9 \mathrm{c}$

Arroyo, J. (11 de Marzo de 2020). Sanidad hoy. Obtained from redacción médica: https://www.redaccionmedica.com/secciones/sa nidad-hoy/coronavirus-pandemia-brote-decovid-19-nivel-mundial-segun-oms-1895

Comisión Económica para América Latina y del Caribe [CEPAL]. (April 3, 2020). América Latina y el Caribe ante la pandemia del COVID19. Efectos económicos y sociales. Retrieved April 20, 2020, from: https://repositorio.cepal.org/bitstream/handle/11 362/45337/S2000264_es.pdf?sequence=4\&isAl lowed=y

Cortés, M. E. (Enero de 2020). Coronavirus como amenaza a la salud pública. Revista médica de Chile, 148(1), 123-129. doi:http://dx.doi.org/10.4067/S0034-

98872020000100124

Cruz Reyes, G., \& Patiño Fierro, M. P. (2020). Las medidas del Gobierno Federal contra el virus SARS-CoV2 (COVID-19). Cuaderno de Investigación. No 6, DGDyP/IBD, CDMX. Retrieved April 21, 2020, from: http://www.bibliodigitalibd.senado.gob.mx/bitst ream/handle/123456789/4832/CuadernoDeInve stigaci\%c3\%b3n_6\%20vf1.pdf?sequence=1\&is Allowed=y
Díaz, V. J., Peña, H. D., Macías, M. D., \& Moreno, C. G. (Julio de 2019). Competencias Tic en Docentes de Educación Superior: Nuevos Escenarios para nuevos retos en los Procesos de Enseñanza Aprendizaje. SINAPSIS. La revista científica del ITSUP, 1(14). Retrieved June 02, 2020, from: https://dialnet.unirioja.es/servlet/articulo?codig $\mathrm{o}=7471182$

El Universal. (21 de Abril de 2020). Casos positivos de VOCID-19 en Yucatán, Quintana Roo y Tabasco al 20 de abril. Estados. Retrieved June 12, 2020, from: https://www.eluniversal.com.mx/estados/casosde-covid-19-en-yucatan-quintana-roo-ytabasco-al-20-de-abril

Espinoza, F. E., \& Ricaldi, E. M. (02 de Junio de 2018). El tutor en los entornos virtuales de aprendizaje. Universidad y Sociedad, 10(3). Retrieved July 02, 2020, from: http://scielo.sld.cu/pdf/rus/v10n3/2218-3620rus-10-03-201.pdf

Ezeiza Pohl, C. E., Ferrero, E. D., Madrid, L. C., Codecido, H. G., Pousada, G. E., \& Vázquez Sowa, M. C. (2016). Factibilidad de aplicación de los recursos educativos abiertos (REA) en los procesos de enseñanza-aprendizaje en modalidad virtual en las carreras de grado de Ciencias Económicas en la Universidad Nacional de la Matanza. XI Congreso de Tecnología en Educación y Educación en Tecnología (TE\&ET 2016), (págs. 311-317). Retrieved July 20, 2020, from: http://sedici.unlp.edu.ar/handle/10915/54568

Feito, A. R. (2020). Este es el fin de la escuela tal y como la conocemos. Unas reflexiones en tiempo de confinamiento. Revista de Sociología de la Educación. RASE, 3(2), 156-163. doi:http://dx.doi.org/10.7203/RASE.13.2.17130 
Fernández, M., Hernández, D., Nolasco, R., de la Rosa, R., \& Herrera, N. (13 de Abril de 2020). Lecciones del COVID-19 para el sistema educativo mexicano. Nexos. Distancia por Tiempos. Retrieved July 02, 2020, from Blog de Educación:

https://d1wqtxts1xzle7.cloudfront.net/62464255 /covid0120200324-96153-

8on28r.pdf?1585072626=\&response-contentdisposition=inline $\% 3 \mathrm{~B}+$ filename $\% 3 \mathrm{DLeccione}$ s_del_COVID-

19_para_el_sistema_e.pdf\&Expires $=15943405$ 69\&Signature $=$ gxh2jvlyAHN5Bihrhex42yf8P4 PjjQU-8bCqlwJ

Galeana-Victoria, L. G., Flores-Azcano, N. P., Gacía-León, L., \& Ruiz-Nartínez, J. C. (Junio de 2016). Edublogs para el autoaprendizaje en modelos basadosen competencias. Revista de Docencia e Investigación Educativa, 2(4), 1-10. Retrieved June 02, 2020, from https://dialnet.unirioja.es/servlet/articulo?codig $\mathrm{o}=7473664$

Gobierno del Estado de Yucatán. (13 de Marzo de 2020). Ruida de prensa de la Secretaría de Salud del Gobierno del Estado de Yucatán. Facebook Watch. Obtained from https://www.facebook.com/watch/live/?v=1591 $162481036717 \&$ ref=watch_permalink

Guerra, J. (20 de Abril de 2020). Declaración conjunta de la UIT y la OMS: Desencadenar el potencial de la tecnología de la información para derrotar la COVID-19. Centro de Prensa. Retrieved April 20, 2020, de Organización Mundial de la Salud: https:/www.who.int/es/news-room/detail/2004-2020-itu-who-joint-statement-unleashinginformation-technology-to-defeat-covid-19

Instituto Nacional de Estadística y Geografía [INEGI]. (2015). Información por entidad. Población. Inegi. Retrieved April 23, 2020, from INEGI:

http://cuentame.inegi.org.mx/monografias/infor macion/camp/poblacion/default.aspx $?$ tema $=$ me $\& \mathrm{e}=04$

La Jornada. (March 23, 2020). Campeche registra primer caso de Covid-19. Estados. Retrieved May 30, 2020, from https://www.jornada.com.mx/ultimas/estados/2 020/03/23/campeche-registra-primer-caso-decovid-19-2936.html
La Jornada. (February 27, 2020). En Brasil, el primer caso de Covid-19 en América Latina. Mundo. Obtained from https://www.jornada.com.mx/ultimas/mundo/20 20/02/27/en-brasil-el-primer-caso-de-covid-19en-america-latina-4606.html

Martos, E. F., \& Teruel, S. M. (2018). PLATAFORMAS VIRTUALES EN ELE: ANÁLISIS Y EVOLUCIÓN DEL AULA VIRTUAL DE ESPAÑOL (AVE), SEGÚN CREENCIAS DE SU PROFESORADO. MarcoELE: Revista de Didáctica Español Lengua Extranjera(26), 1-16. Retrieved June 30, 2020, from https://marcoele.com/descargas/26/martosteruel_ave.pdf

Meneses, J. (2016). El cuestionario. Retrieved December 20, 2020, from: http://femrecerca.cat/meneses/publication/cuesti onario/cuestionario.pdf

Moreira, M. A. (March 2012). ¿AL FINAL, QUÉ ES APRENDIZAJE SIGNIFICATIVO? Revista Qurriculum(25), 29-56. Retrieved December 18, 2020, from: https://riull.ull.es/xmlui/bitstream/handle/915/1 0652/Q_25_\%282012\%29_02.pdf?sequence=5 \&isAllowed $=\mathrm{y}$

Salinas, M. I. (April 1, 2011). Entornos virtuales de aprendizaje en la escuela: tipos, modelo didáctico y rol del docente. Universidad Católica de Argentina, Eduteca ICESI. Retrieved April 01, 2020, from: http://eduteka.icesi.edu.co/gp/upload/Educaci\% C3\%B3n\%20EVA.pdf

Sánchez Mendiola, M., Martínez Hernández, A. M., Torres Carrasco, R., de Agüero Servín, M. d., Hernández Romo, A. K., Benavides Lara, M. A., . . . Rendón Cazales, V. J. (2020). Retos educativos durante la pandemia de covid-19: una encuesta a profesores de la UNAM. Revista Digital Universitaria (RDU). Retrieved June 20, 2020, from: https://www.revista.unam.mx/prensa/retoseducativos-durante-la-pandemia-de-covid-19una-encuesta-a-profesores-de-la-unam/ 
Sarmiento-Espinoza, W. H., Erreyes-Cobos, J. P., Quinlllin-Hidalgo, J. V., \& Yamba-Espinoza, D. P. (Mayo de 2020). Educación virtual como herramienta tecnológica de apoyo en nivel superior ecuatoriano. 5. Edición 45(05), 95-115. doi:10.23857/pc.v5i5.1405

Secretaría de Educación Pública [SEP]. (2019). Principales cifras del sistema educativo nacional 2018-2019. Ciudad de México: Dirección general de Planeación, Programación y Estadística Educativa. Retrieved April 23, 2020, from: https://www.planeacion.sep.gob.mx/Doc/estadi stica_e_indicadores/principales_cifras/principal es_cifras_2018_2019_bolsillo.pdf

Secretaría de Salud México. (April 20, 2020). Reporte diario del COVID-19. Obtained from: https://www.youtube.com/watch?time_continue $=2 \& v=q 8$ PwZk4S-9A\&feature=emb_title

Secretaría de Salud Quintana Roo. (May 30, 2020). COVID-19. Facebook. Obtained from: https://www.facebook.com/SESAQROO/posts/ covid-19hemos-identificado-el-primer-casopositivo-en-quintana-roolas-personasq/3184887118240028/

Valdez-García, J. E., López Cabrera, M. V., Jiménez, M. M., Díaz, E. J., Dávila Rivas, A. G., \& Olivares, O. S. (July-September 2020). Me preparo para ayudar: respuesta de escuelas de medicina y ciencias de la salud ante COVID-19. 9(35).

doi:https://doi.org/10.22201/facmed.20075057e .2020 .35 .20230

Vargas, L. C., \& Jiménez, S. S. (Julio-Diciembre de 2013). Constructivismo en los Procesos de Educación en Línea. Ensayos Pedagógicos, VIII(2), 157-167. Retrieved July 01, 2020, from: https://dialnet.unirioja.es/servlet/articulo?codig $\mathrm{o}=5409440$
Vega-Malagón, G., Ávila-Morales, J., VegaMalagón, A. J., Camacho-Calderón, N., Becerril-Santos, A., \& Leo-Amador, G. E. (2014). PARADIGMAS EN LA INVESTIGACIÓN. ENFOQUE CUANTITATIVO Y CUALITATIVO. European Scientific Journal, 10(15), 523-528. Retrieved 2020 December 29, from: https://d1wqtxts1xzle7.cloudfront.net/61258898 /3477-1-10011-1-10-201405302019111844529-1 gutn4z.pdf?1574130965=\&responsecontent-

disposition $=$ inline $\% 3 \mathrm{~B}+$ filename $\% 3 \mathrm{DPARADI}$ GMAS_EN_LA_INVESTIGACION_ENFOQ UE_C.pdf\&Expires $=1609277480 \&$ Signature $=L$ 6QsAFMIqP53ZgCLbGs

Verdencia, C. E., Cecilia, E. S., \& Jimena, P. M. (October 2016). Docentes en línea. Didáctica, Innovación y Multimedia (34), 1-18. Retrieved June 20, 2020, from: http://dimglobal.net/revista34.htm

Villegas-Chiroque, M. (2020). Pandemia de COVID-19: pelea o huye. Revista Experiencia en Medicina del Hospital Regional Lambayeque, 6(1), 3-4. 